\title{
BIOEDUSCIENCE
}

ISSN: 2614-1558

\section{E-Learning Based Motion Graphics Media to Improve Student Motivation on Biodiversity Material}

\author{
Ervan Johan Wicaksana ${ }^{1 *}$, Binanggra Alpa Pebriand1, Pramana Atmadja², Wikanso² \\ 1Pendidikan Biologi, Universitas Jambi. Jalan Jambi-Muara Bulian Km. 15, Jambi Luar Kota, Muaro Jambi 36112 \\ 2 Pendidikan Bahasa Inggris, Universitas PGRI Madiun, Jl. Setya Budi, Madiun, 63217 \\ *Corespondent Email: ervan_jw@unja.ac.id
}

\section{ARTICLE INFO}

\section{Article history}

Received: 13 Jun 2020

Accepted: 19 Mar 2021

Published: 30 Apr 2021

\section{Keywords:}

Biodiversity

E-Learning

Motion Graphics

\section{A B S T R A C T}

Background: Biology is pure science that is analytical and systematic. It relates to the reality of the problems experienced by students in the current biology learning process, which is a monotonous way of learning and tends to make students feel bored with the learning process carried out so that the teaching material delivered by the teacher or educator is challenging to understand by students. This class action research aims to improve student learning motivation on Biodiversity material. Methods: This class action research was conducted in two cycles; the first cycle was carried out with one meeting, and the second cycle was carried out with one meeting. Each cycle is applying Kemmis and Mc Taggart's classroom action research consisting of 4 stages: planning, action, observation, and reflection. Results: The results of this study are an increase in students' learning motivation in each cycle. Conclusions: It can be concluded that the Motion Graphics learning media based on e-learning has succeeded in increasing students' learning motivation on Biodiversity material.

Media Motion Graphics Berbasis E-Learning Untuk Meningkatkan Motivasi Belajar Siswa Materi Keanekaragaman Hayati

\section{A B S T R A K}

Background: Biologi merupakan ilmu murni yang bersifat analitis dan sistematis. Hal tersebut berkaitan dengan realita permasalahan yang dialami oleh peserta didik pada proses pembelajaran biologi saat ini, yaitu cara belajar yang monoton dan cenderung membuat peserta didik merasa jenuh dengan proses pembelajaran yang dilakukan, sehingga bahan ajar yang disampaikan oleh guru atau pendidik sulit dipahami oleh peserta didik. Penelitian tindakan kelas ini bertujuan untuk meningkatkan motivasi belajar siswa pada materi Keanekaragaman Hayati di kelas X MIA 1. Penelitian tindakan kelas ini dilakukan dengan dua siklus, siklus I dilaksanakan dengan satu kali pertemuan dan siklus II dilaksanakan dengan satu kali pertemuan. Setiap siklus merupakan penerapan penelitian tindakan kelas model Kemmis dan Mc Taggart yang terdiri dari 4 tahapan: perencanaan, tindakan, observasi, dan refleksi. Hasil penelitian ini adalah terjadinya peningkatan motivasi belajar peserta didik pada tiap siklus dengan interpretasi tinggi menunjukkan angka $82 \%$. Berdasarkan hasil penelitian tersebut, dapat ditarik kesimpulan bahwa media pembelajaran Motion Graphics berbasis e-learning berhasil meningkatkan motivasi belajar peserta didik pada materi Keanekaragaman Hayati.

(C2021 by authors. License Bioeduscience, UHAMKA, Jakarta. This article is open access distributed under the terms and conditions of a Creative Commons Attribution (CC-BY) license.

\section{Introduction}

The development of information and communication technology (ICT) is currently increasingly encouraging renewal efforts in the teaching and learning process. Teachers are required to develop skills in making ICTbased learning media so that learning objectives can be achieved. As one of the media in education, ICT also has a tendency that can encourage students' interest and also provide many benefits to the learning process. $28 \%$ of students' interest in learning is due to teachers (Wicaksana \& Pramana, 2018). This means that many other factors influence students' learning interest, one of which is ICT. One of them is by using learning media. However, the fact is that there are still quite a lot of teaching staff who have not 
used this ICT-based learning media in delivering the material they deliver (Rosdiana, 2018)

Biology is pure science that is analytical and systematic. This is related to the reality of the problems experienced by students in the current biology learning process, namely the monotonous way of learning and tends to make students feel bored with the learning process being carried out so that the teaching materials delivered by the teacher or educator are difficult for students to understand. This happens because of the mismatch between educators' teaching techniques and strategies with the interests and learning patterns of students. The lack of use of instructional media in the teaching and learning process makes it easier for students to convey information. Learning experiences should be integrated with life skills that provide students with provisions in various aspects of life. One aspect of life skills is inserting life skills into instructional media (Wicaksana et al., 2017)

According to (Suryani et al., 2018), media are all forms and channels of conveying messages/information from message sources to recipients that can stimulate thoughts, arouse enthusiasm, attention, and students' will so that students are able to acquire knowledge, skills, or attitudes in accordance with the purpose of the information submitted. According to (Miftah, 2013), media is defined as the maximum use of all system components and learning resources to achieve certain learning objectives.

Learning media cannot be separated from a teaching and learning process in order to achieve educational goals in general and learning objectives in schools in particular. According to (Maulana \& Firdian, 2017) the benefits of learning media are as messengers in learning objectives, learning media also facilitate communication between students and teachers and can improve learning. So that in modern times, learning media is needed that can deliver students' understanding in solving problems in the learning process in the classroom. According to (Wicaksana \& Pramana., 2020), 65\% of students are highly motivated in online learning using ICT even during the Covid-19 pandemic. The role of ICT in education is urgently needed, namely by using learning media that utilize ICT.

The use of instructional media that utilizes ICT can make biology learning easier and more interesting. One alternative media that can be used is Motion Graphics learning media. According to (Wiana, 2017), motion graphics is a combination of design / animation elements based on visual media that combines film language with graphic design, by combining various elements such as 2D or 3D. According to (Kharishma et al., 2018) motion graphics are media that use video recording and or animation technology to create the illusion of motion and are usually combined with audio for use in multimedia output.
According to (Hartanto, 2016) one form of information technology development that can also be used as a learning medium is by using e-learning. According to (Ariani, 2018) e-learning is learning with the help of electronic devices that make it easier for students to gain access to learning resources in achieving learning goals. In his opinion (Suharyanto \& Mailangkay, 2016), e-learning is a form of a distance learning concept. Teaching materials can be virtualized in various formats to be more exciting and dynamic to motivate students to go further in the learning process.

Motivation is the encouragement of someone consciously or unconsciously to carry out an activity to achieve his goals (Pebruanti \& Munadi, 2015). According to (Sumiati, 2018), motivation is to direct and regulate individual behaviour. Motivation in real life is often described as guiding, directing and orienting a specific goal of the individual. Learning motivation is the nurturer or guides for students' behaviour and innate strength (Ricardo \& Meilani, 2017). According to (Novalinda et al., 2017), learning motivation is the entire driving force in students or students that creates interest in learning to achieve the desired goals in learning. According to (Saputri et al., 2018), learning motivation is an internal and external push for students learning to make behavioural changes with several indicators or supporting elements.

Based on preliminary observation data and the author's experience while being a student, it shows the low interest of students in learning biology if learning activities are carried out without using learning media which can be seen through the following diagram:

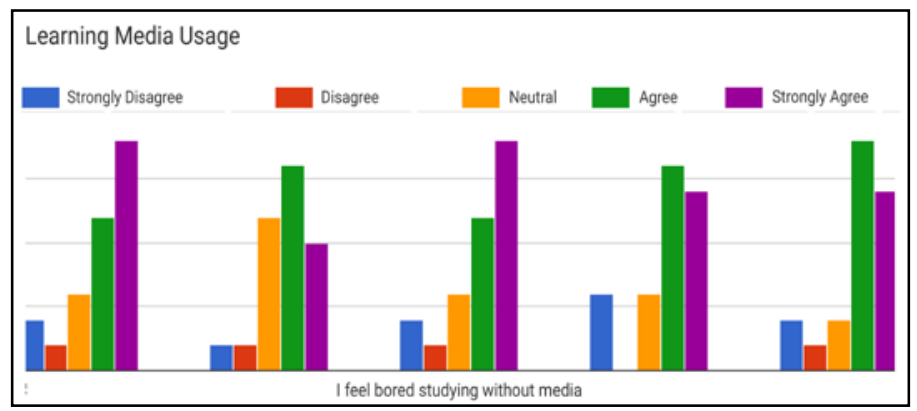

Figure 1. Preliminary Observation Data

Research by (Ridho et al., 2017) also concluded that there was an increase in learning motivation that was higher in students with similar learning media, namely animation. These media make it easier for students to understand the material and increase students' positive attitude in participating in learning. Therefore, researchers used Motion Graphics learning media to increase students' learning motivation in Biology subjects, especially in Biodiversity material. 


\section{Method}

This research is action research (action research) conducted in the classroom or classroom action research (Classroom Action Research). Classroom action research is research conducted by teachers in the classroom by (1) planning, (2) implementing (3) observing and (4) reflecting on collaborative and participatory actions with the aim of improving their performance as a teacher so that student learning outcomes can increase.

\section{Research Procedure}

The application of the model in classroom action research was carried out in two cycles. Cycle I was carried out with one meeting and cycle II was carried out with one meeting. Each cycle is an application of the class action research model of Kemmis and Mc Taggart which consists of 4 stages, namely planning, action, observation, and reflection as illustrated in the chart below:

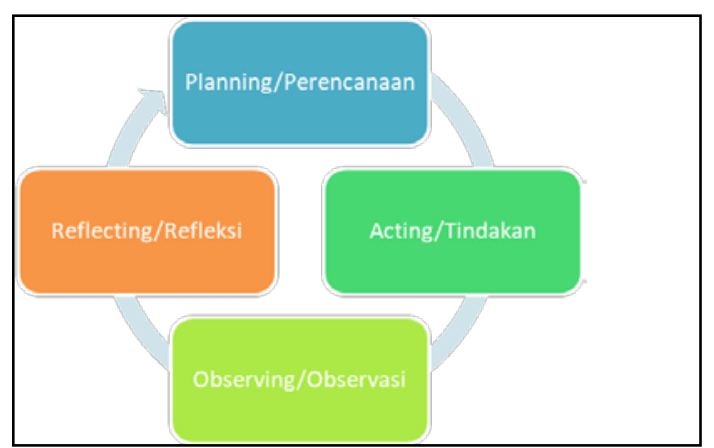

Figure 1. Cycle Stages

The first stage in this research is planning, which is to reflect and analyze the problems that occur in the learning process and look for alternative solutions to problems. The second stage is action, namely applying the Direct Instruction method using E-Learning-based Motion Graphics learning media referring to the lesson plans prepared. The third stage is observation, namely collecting and compiling data obtained from the learning process. The fourth stage is reflection, namely analyzing the data obtained from the learning process using E-Learning-based Motion Graphics learning media such as the results of observations of student activities and teacher and student interviews after the learning process takes place.

\section{Data Collection and Data Analysis}

Data collection techniques used in this research are observation, questionnaires, interviews and documentation. The percentage of student activity in learning is calculated using the formula proposed by (Sudijono, 2006).

$$
P=\frac{F}{N} \times 100 \%
$$

Annotation:

\section{$\mathrm{P}=$ Percentage}

$\mathrm{F}=$ the number of students who are active

$\mathrm{N}=$ total number of students

If the percentage of student activeness is known, then we can classify the activeness of these students into their respective groups as stated by (Arikunto, 2007), namely:

$\mathrm{A}=81 \%-100 \%$ (Very good)

$\mathrm{B}=61 \%-80 \%$ (Good)

$\mathrm{C}=41 \%-60 \%$ (Enough)

$\mathrm{D}=21 \%-40 \%$ (Less)

$\mathrm{E}=0 \%-20 \%$ (Very little)

\section{Result}

The results of preliminary observations at Senior High School 2 in Tebo Regency show that students' learning interest or motivation is still low. This happens because in previous learning, media was not used in learning.

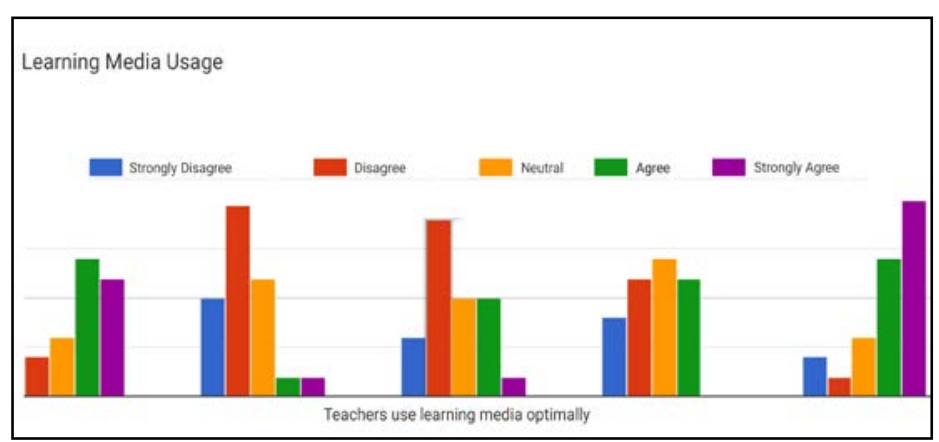

Figure 3. Cycle I Data

Based on data in cycle I, there is still a positive response to negative statements, meaning that the respondent agrees with the negative statement. The data stated that there were still deficiencies in cycle I, namely the use of learning media that was not optimal so that it could not significantly lead to learning motivation for students. However, some students were motivated enough by the use of e-learning based Motion Graphics learning media.

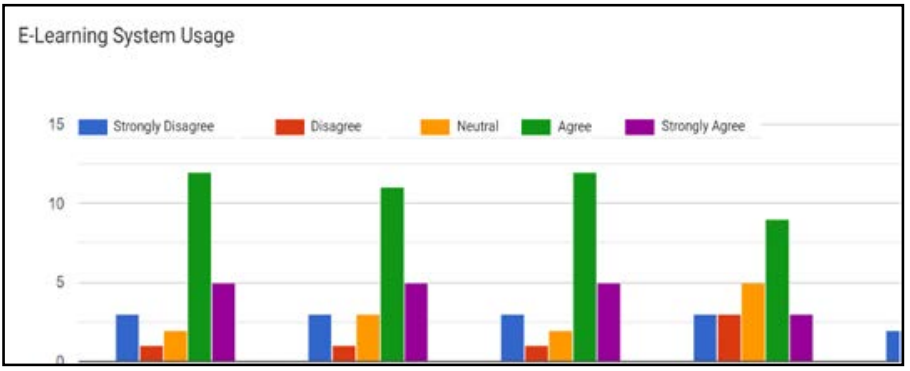

Figure 4. Cycle II Data

Based on the diagram data in cycle II, a significant increase in positive responses occurred by implementing an integrated e-learning system with Motion Graphics learning media. This increases students' motivation to learn very well. There were fewer negative responses and a significant difference between positive responses. This can be caused by technical constraints on learning with an 
online system, such as poor network quality so that learning becomes obstructed.

\section{Discussion}

This classroom action research has a cycle. Where each cycle helps improve students' learning process, in this study, researchers used 2 cycles, namely cycle I and cycled II. For cycle, I, includes planning, action, savings and reflection. At the planning stage, in the first cycle, the researcher used Motion Graphic learning media on Biodiversity material, then the educator presented the learning material using a Motion Graphic which later students were asked to listen to explanations from the educators and would give assignments. Furthermore, in the observation stage, the educator saw students' lack of motivation in following this online learning, the students' common knowledge of the material being taught, and was less active in the learning process. Moreover, in the reflection stage, seeing that interest in learning is still lacking, it can be seen that when the learning process takes place students are not enthusiastic about listening to the material from educators and there is no learning motivation. For this reason, researchers conducted a second cycle to increase student learning motivation.

Furthermore, in the planning stage of cycle II it is still the same as cycle I where educators use Motion Graphic learning media in explaining Biodiversity material, but with some optimization of the e-learning system. Furthermore, at the stage of carrying out the action of the educator presenting material with motion graphics learning media and it was seen that students were getting used to learning media through this e-learning system, students began to be active during the learning process. This proves that students are motivated by e-learning based Motion Graphics learning media on biodiversity material. Then the observation stage, at this stage in cycle II, there were no more passive students who were almost entirely involved in learning and it was seen that students easily understood the material presented by the educator. And the last stage of reflection clearly proves that students are motivated in learning by using e-learning based Motion Graphics learning media. It can be seen that e-learning-based Motion Graphics media can help students understand the material and increase learning motivation.

Based on the explanation of the research results, it can be concluded that most of the students of class X MIA 1 SMA Negeri 2 Tebo Regency have a high level of learning motivation. This shows that the students of class X MIA 1 SMA Negeri 2 Tebo Regency already have learning motivation but have not developed optimally.

Students of class X MIA 1 Senior High School 2 in Tebo Regency have the motivation to learn. The high level of student motivation factors can be seen from several aspects as described by, first, the desire and desire to succeed.
Students have a strong desire to successfully master the material and get high scores in their learning activities. This can be seen from individuals who have high achievement motives, such as completing their assignments to completion, not procrastinating their work, and willing to ask teachers or friends if there are lessons that have not been understood.

Second, there is encouragement and need in learning. Students interested in learning will participate in teaching and learning activities with pleasure to think that learning is a need, not just an obligation. Motivation is closely related to the need for learning. Students cannot avoid a need to master many sciences because that is why students learn. This can be seen in examples such as students feel disadvantaged if they do not attend lessons, have the desire to reread the lesson notes that have been made, want to study material that the teacher has not taught, and continue to study independently.

Third, there are hopes and dreams for the future. Expectations are based on the belief that people are influenced by how they feel about the results of their actions. This can be seen from individuals who have a clear picture and goals for their future, such as students who study hard because they want to be smart students in class, will continue to study in order to get the highest score in the class, and want to have many learning achievements. However, the reality in this class is that not all students have the effort and the intention to achieve their hopes and dreams.

Fourth, there is an appreciation for learning. Verbal statements or other forms of appreciation for good behaviour or learning outcomes are the easiest and most effective way to increase learning motivation. This can be seen from individuals who are enthusiastic about learning to get a compliment from others, such as pride if friends give praise for getting good grades, and are happy when their parents congratulate them when they are ranked in class. The reality in this class is that not all students care about the praise given to them. They consider that praise is normal, so it does not affect their motivation to learn.

Fifth, some activities are interesting in learning. This can be seen from the attractive atmosphere causing the learning process to be meaningful. Something meaningful will always be remembered, understood, and appreciated, such as students like to study in groups with their friends because they can exchange ideas and information. In fact, in class X MIA 1 Senior High School 2 in Tebo Regency, not all students want to study in groups because they can only study alone without other people.

Sixth, there is a conducive learning environment. A conducive learning environment is one of the driving factors for students' learning. Thus students can obtain appropriate assistance in overcoming difficulties or problems in learning. This can be seen from the individual 
feeling comfortable in the environmental situation they study, such as students who are comfortable taking lessons online because they can study well in a calm and comfortable atmosphere.

According to (Saputri et al., 2018), the learning process using multimedia can activate students to learn with high motivation because of their interest in multimedia, providing text, images, video, audio, and animation. The combination of text, images, video, audio and animation can be a practical resource for students. The more senses used in receiving information and processing, the more information will be received and long-lasting in memory.

According to (Ampa et al., 2013), the implementation of Motion Graphics in learning is very practical and effective. This is indicated by the excellent student response and teacher response to the media. In addition, the effectiveness of the use of the media is also marked by a significant difference in scores between the students' pretest and posttest.

Based on research conducted by (Sa'adah et al., 2017), historical learning media in the form of video motion graphics are effective for use in learning Indonesian History in class XI SMA Negeri 1 Bangsri. This is based on the average results of students' interest in learning in the experimental class which has a better difference of 13.2 than the average interest in learning in the control class which is only 7.1.

Research by (Sari, 2019) states that with the use of this motion graphic animation video which is a visual communication medium that can provide more interesting information packaging. Motion graphics, apart from having the function of attracting the attention of the audience, also aims to explain the information message conveyed. In addition, viewers can easily remember concepts and ideas so that viewers are motivated to see and understand the information on the video.

Based on the results of this study, the researcher concluded that the students of class X MIA 1 Senior High School 2 in Tebo Regency actually had a good level of learning motivation but had not developed optimally. This is because students are in the process of developing learning motivation that is within them, such as encouragement and need in learning. However, with Motion Graphics learning media during online learning, students of class X MIA 1 Senior High School 2 in Tebo Regency are very motivated in learning.

\section{Conclusions}

Based on the research that has been carried out, it can be concluded that using e-learning based Motion Graphics learning media can increase students' learning motivation. With the help of the media, it can help students understand the material readily accepted. After being put into practice, the e-learning-based Motion Graphics media used succeeded in making students motivated. This means that the better the application of learning media, the higher the learning motivation of students and the higher the understanding of learning concepts achieved by students.

\section{Declaration statement}

The authors reported no potential conflict of interest.

\section{References}

Ampa, A. T., Rasyid, M. A., Rahman, M. A., Haryanto, H., \& Basri, M. (2013). The Implementation of Multimedia Learning Materials in Teaching English Speaking Skills. International Journal of English Language Education, 1(3), https://doi.org/10.5296/ijele.v1i3.4153

293.

Ariani, D. (2018). Komponen Pengembangan E-Learning. Jurnal Pembelajaran Inovatif, 1(1), 58-64. https://doi.org/10.21009/JPI.011.09

Arikunto. (2007). Prosedur Penelitian Suatu Pendekatan Praktik. Rineka Aksara.

Hartanto, W. (2016). Penggunaan E-Learning sebagai Media Pembelajaran. Jurnal Pendidikan Ekonomi, 10(1), 118.

Kharishma, V., Firnandi, R., Iqbal, M., \& Krishnasari, E. D. (2018). Perancangan Motion Graphic Untuk Iklan Layanan Masyarakat Berjudul Go Green Dengan Rumah Ekologis. Prosiding Seminar Nasional Teknologi Informasi Dan Multimedia, 1(1), 1-6.

Maulana, I. T., \& Firdian, F. (2017). Perancangan Media Pembelajaran Multimedia Interaktif Untuk Mata Kuliah Aplikasi Software. Jurnal Sains Dan Informatika, 3(12), 89-96.

Miftah, M. (2013). Fungsi dan Peran Media Pembelajaran Sebagai Upaya Peningkatan Kemampuan Belajar Siswa. Jurnal Kwangsan, 1(2), 95. https://doi.org/10.31800/jurnalkwangsan.v1i2.7

Novalinda, E., Kantun, S., \& Widodo, J. (2017). Pengaruh Motivasi Belajar Terhadap Hasil Belajar Mata Pelajaran Akuntansi Siswa Kelas X Jurusan Akuntansi Semester Ganjil SMK PGRI 5 Jember Tahun Pelajaran 2016/2017. Jurnal Pendidikan Ekonomi, 11(2), 115119. https://doi.org/10.19184/jpe.v11i2.6456

Pebruanti, L., \& Munadi, S. (2015). Peningkatan Motivasi Dan Hasil Belajar Pada Mata Pelajaran Pemograman Dasar Menggunakan Modul Di SMKN 2 Sumbawa. Jurnal Pendidikan Vokasi, 5(3), 365 https://doi.org/10.21831/jpv.v5i3.6490

Ricardo, R., \& Meilani, R. I. (2017). Impak Minat dan Motivasi Belajar Terhadap Hasil Belajar Siswa. Jurnal Pendidikan Manajemen Perkantoran, 2(2), 79. https://doi.org/10.17509/jpm.v2i2.8108

Ridho, M., Hasruddin, H., \& Djulia, E. (2017). Pengaruh Penggunaan Media Animasi dan Pengetahuan Awal Siswa Terhadap Hasil Belajar Siswa pada Materi Sistem Pencernaan Makanan Manusia di Sekolah Menengah Pertama. Jurnal Pendidikan Biologi, 7(1), 
Rosdiana, R. (2018). Penggunaan Media Pembelajaran Berbasis ICT Dan Pengaruhnya Terhadap Tingkat Kelulusan Ujian Nasional Siswa Pada Sekolah Menengah Di Kota Palopo (Studi Kasus Di 5 Sekolah Menengah Di Kota Palopo). Al-Khwarizmi: Jurnal Pendidikan Matematika Dan Ilmu Pengetahuan Alam, 4(1), 73-82. https://doi.org/10.24256/jpmipa.v4i1.253

Sa'adah, I., Prmono, S. E., \& Suharso, R. (2017). Pengembangan Media Video Motion Graphic Sejarah Pemerintahan Herman Willem Daendels (1808-1811) dalam Pembelajaran Sejarah Indonesia Untuk Meningkatkan Minat Belajar Siswa Untuk SMA. Indonesian Journal of History Education, 5(1), 25-31.

Saputri, Y. E., Ismail, I., \& Mulyani, S. (2018). Meningkatkan Motivasi Belajar Simulasi Digital Melalui Pemanfaatan Edmodo Pada Siswa Sekolah Menengah Kejuruan. Jurnal Komunikasi Pendidikan, 2(2), 132. https://doi.org/10.32585/jkp.v2i2.126

Sari, I. P. (2019). Perancangan Video Edukasi Animasi 2 Dimensi Berbasis Motion Graphic Mengenai Bahaya Zat Adiktif untuk Remaja. Edsence: Jurnal Pendidikan Multimedia, 1(1), 43-52. https://doi.org/10.17509/edsence.v1i1.17957

Suharyanto, \& Mailangkay, A. B. L. (2016). Penerapan ELearning Sebagai Alat Bantu Mengajar Dalam Dunia Pendidikan. Jurnal Ilmiah Widya, 3, 17-21. https://doi.org/10.1016/j.neubiorev.2016.02.001

Sumiati, S. (2018). Peranan Guru Kelas Dalam Meningkatkan Motivasi Belajar Siswa. TARBAWI: Jurnal Pendidikan Agama Islam, 3(02), 145-164. https://doi.org/10.26618/jtw.v3i02.1599

Suryani, N., Setiawan, A., \& Aditin Putria. (2018). Media Pembelajaran Inovatif dan Pengembangannya (Pipih Latifah (ed.)). PT. Remaja Rosdakarya.

Wiana, W. (2017). Application Design of Interactive Multimedia Development Based Motion Graphic On Making Fashion Design Learning In Digital Format. International Journal of Scientific \& Technology Research, 6(5), 102-108.

Wicaksana, E. ., Maridi., \& Sutarno, S. (2017). Efektivitas Modul Pembelajaran Biologi Berorientasi Integrated Scientific Process untuk Meningkatkan Vocational Skills Siswa SMA. Jurnal Pendidikan Biologi, 8(2), 6469.

Wicaksana, E. J., \& Pramana., A. (2020). Efektifitas Pembelajaran Menggunakan Moodle Terhadap Motivasi dan Minat Bakat. EduTeach, 1(2), 117-124. https://doi.org/https://doi.org/10.37859/eduteach

Wicaksana, E. J., \& Pramana, A. (2018). Analysis of the Impact of Teacher Program Direktorat PSMK ( SM3T Program ) to Animo Learning Students in Biological Lessons In SMKN 1 Kintamani , Bali (Analysis of the Impact of Teacher Program Direktorat PSMK ( SM3T Program ) to Animo Learning Students. Biodik, 4(2), 